\author{
Vlaho Kovačević \\ Sveučilište u Splitu, Filozofski fakultet, Poljička cesta 35, HR-21000 Split \\ vkovacevic@ffst.hr
}

\title{
Od sekularizacije religije do revitalizacije religije
}

\begin{abstract}
Sažetak
Cilj je ovoga rada otvaranje prostora mogućoj revitalizaciji religije izvan ideološkoga koncepta dijalektike suvremenoga društva, a unutar povijesnoga konteksta specifičnoga značenja sekularizacije religije. Razumijevanje religije nužno ostaje s onu stranu dijalektike svjetovnosti, s obzirom na to da religija ne ovisi o toj dijalektici nego o Svetom $i$ njegovu razumijevanju. Bez njega bili bismo u situaciji »stalnog vraćanja istoga" koje u sebi ima $i$ negativne posljedice na čovjekov život u vidu suvremenih modernih ideologija. Iz navedenoga proizlazi potreba za višedimenzionalnim teorijskim pristupima proizišlima iz složenosti društvenih prilika $i$ različitih razvojnih puteva religije u suvremenosti. Time nam teorijski pristupi religiji u suvremenom društvu, koji su analizirani na temelju dominantnih teorija, ponajprije funkcionalizma, fenomenologije i neoweberijanizma, pokazuju različite paradigme kroz različita razumijevanja sekularizacije i revitalizacije religije.
\end{abstract}

\section{Ključne riječi}

sekularizacija, religija, Sveto, racionalizacija, raščaranost, Max Weber, sociologija religije

\section{Uvod}

Pitanje sekularizacije i revitalizacije religije unutar odnosa religioznoga i svjetovnoga provocira sociološku imaginaciju da napravi iskorak u dosad »nepoznate slojeve« religije. Stoga, osim općeg iskaza klasika sociologije (Émile Durkheim, Max Weber) i suvremenih važnijih predstavnika značajnih za sociološku analizu sekularizacije (Bryan R. Wilson, Thomas Luckmann, Peter L. Berger, Steve Bruce i Karel Dobbelaere), u ovom radu uvršteni su i važniji predstavnici kritike socioloških teorija procesa sekularizacije (Jeffrey K. Hadden, Rodney Stark i Mark Chaves). Potreba za višedimenzionalnim teorijskim pristupom složenosti proizlazi iz društvenih prilika i različitih razvojnih puteva religije u suvremenosti, a koji pak nisu ravnodušni u odnosu na religiju. Jednako tako religija, nudeći se sociološkoj i fenomenološkoj refleksiji, pokazuje bogatu paletu interpretativnih izazova koji nisu lišeni i određenih manjkavosti.

»Ove potonje iznova hrane elan religije na crti njenog uzleta u kontekstu moderne praveći iskorak koji nije lišen neizvjesnosti u područje postmoderne. ${ }^{1}$

Različiti teorijski pristupi sekularizaciji religije, kao pojavnosti, nastoje se uvijek iznova nadvladati kako unutar jednostranosti pojedinih teorija sekularizacije, tako i unutar njihove plošnosti u kritičkom pristupu navedenih te-

Vlaho Kovačević, Sekularizacija, modernitet $i$ katolički ethos (disertacija), Filozofski fakultet Sveučilišta u Zagrebu, Odsjek za sociologiju, Zagreb 2012., str. III. 
orija. Otuda potreba za uviđanjem granica sekularizacije, odnosno stanovite relativizacije, ma koliko bile misaono superiornije unutar različitih teorija sekularizacije. ${ }^{2} \mathrm{O}$ tome na poseban način progovaraju Esad Ćimić i Željko Mardešić (Jakov Jukić).

Tema predstavlja dvostruki proces. Jedan od procesa sekularizacije jest $\mathrm{u}$ njegovu »reaktivnom《 odnosno »dijalektičkom « karakteru pa ju je moguće razumjeti, s jedne strane, kroz povijesni proces osvještavanja transcendentnoga, čime se pojačava racionalizacija sekularizacije, a slabi političnost religije i otvara prostor za jačanje religioznosti, bilo izvan, bilo u samim crkvama. S druge strane, kao reakcija na navedeno, otvara se novi krug beskonačne igre institucionalne i izvaninstitucionalne religioznosti. No ona u bîti i dalje »nema nikakve veze sa zbiljskim 'predmetom' religioznosti, s onim što ostaje s onu stranu ove dijalektičko-povijesne igre «. ${ }^{3}$

Drugi je proces u sferi vjerovanja i kulture, raščaranost i ponovni »povratak svetoga« za procese desekularizacije u sferi vjerovanja i kulture.

»Ova tendencija, koja je zaista vrlo snažna, ima vrlo različite korijene od procesa racionalizacije (čiji su razlozi tehnološki i ekonomski). $\ll^{4}$

Američki sociolog postindustrijskog društva Daniel Bell znanost ostavlja postrani

»... ne samo zbog njezinih ranih poveznica s puritanizmom nego zato što samo jedan dio znanosti podržava racionalizaciju - pod utjecajem Bacona ili procesa sekularizacije (čiji su korijeni bili prvenstveno politički, u smanjenju crkvene moći). $\ll^{5}$

Religija time ukazuje na preduvjete društvenokulturnog plana sekularizacije, dok religioznost ukazuje na preduvjete sekularizacije na pojedinačnom planu. ${ }^{6}$ Pojam duhovnosti više je osobne naravi, dok je pojam religioznosti više vezan uz zajednicu i institucije. ${ }^{7}$ To znači da religija ne može postati životnom doli putem povijesnopojedinačnog posredovanja života i da konkretna religioznost ne nastaje bez svakidašnjeg društvenokulturnog uobličenja i posredovanja. ${ }^{8}$ Poradi boljeg razumijevanja (post)moderne revitalizacije religije, potrebno je na početku razmotriti povijesni kontekst procesa sekularizacije, koji je ne samo vremenski prethodio nego je i posljedično utjecao na »povratak svetoga $\ll,{ }^{9}$ odnosno na suvremenu revitalizaciju religije i religioznosti.

\section{Povijesni kontekst sekularizacije religije}

U povijesnom kontekstu, od kraja XVIII. do sredine XIX. stoljeća gotovo su svi mislioci prosvjetiteljstva očekivali da će religija nestati u XX. stoljeću. S obzirom na to da je prosvjetiteljstvo razdoblje u kojem većina mislioca svoje uvjerenje temelji na moći razuma, ne čudi njihov stav da je religija povezana s praznovjerjem i vjerovanjima

»... koja se ne mogu dokazati, oblikom straha koji se koristio kao zaštita od drugih strahova i za koji su vjerovali kako je nastao u razdoblju 'djetinjstva' čovječanstva. $\ll^{10}$

Razlikujemo više tipova osporavanja religije, od kojih su najznačajnija antireligiozna kritika i antropocentrična kritika.

Razumijevanje religije kroz antireligioznu kritiku sastoji se od svrstavanja prikaza, doživljaja i simboličkih medijacija Svetog među iracionalne produkte ljudskog duha, koji su često bili iskorištavani od strane vlastī kojima je bilo $\mathrm{u}$ interesu držati ljude u lakovjernosti. ${ }^{11}$ Johan Huizinga piše da se pri kraju srednjeg vijeka događa svojevrsna manipulacija simbolizma, koji postaje arbitrarna alegorija, prije nego što na svijet donese mitologiju koja će za renesansu 
često biti trivijalna. ${ }^{12}$ Za Romana Guardinija, religiozni život također »klizi prema formuli, prema shemi«, gubi kontakt s esencijalnom strukturom života; više ne obuhvaća egzistenciju, više ne »formira $\ll .{ }^{13}$ Religiozna iluzija potisnuta je u istu demistifikaciju kao Sveto, općenito govoreći (Ludwig Feuerbach, Karl Marx, Sigmund Freud) u ime ateizma koji se prikazuje kao istina. ${ }^{14}$

»Klasično razdoblje, počevši od humanizma, ponovno obnavlja i preuzima to nasljedstvo i inkarnira ga u znanosti, filozofiji ili pravu. Takav je racionalizam često poprimao antireligiozni ili pak manje skeptični i kritični oblik naspram svetog. $^{15}$

Feuerbach reducira Boga na projekciju u transcendentnoj fikciji svojstava ljudskog duha.$^{16}$ Naravno, religija dozvoljava da čovjek spozna svoju univerzalnu bit (fr. essence générique, njem. Gattungswesen), ali po cijenu otuđenja od samog sebe, od čega ga povijest želi osloboditi. ${ }^{17}$

»Na tu se kritiku žestoko nastavlja antireligiozni pokret (M. Stirner, M. Bakunjin itd.) koji pokazuje žestoku mržnju spram Boga, što pronalazimo u prvim radovima K. Marxa, koji sanja vidjeti slom 'patuljastog diva' i kroz čije se ruševine (Marx) osjeća 'jednak Stvoritelju'. Marx kasnije reducira religiju na ideološki produkt koji skriva konfliktne odnose ekonomskih klasa i koči oslobađajuću spoznaju proletarijata. ${ }^{18}$

»Nietzsche u ideji Boga vidi utočište slabosti, odbacivanje života i proriče 'smrt Boga' koja je potrebna za dolazak nove mudrosti. Nedavno se razvilo učenje o 'smrti Boga', koje se, prije svega, brine za izgradnju diskursa o negaciji svega natprirodnog i cijelog teizma (primjerice kod Thomasa Altizera, W. Hamiltona, A. T. Robinsona, P. van Burena itd.). « ${ }^{19}$

Usp. ibid.

Željko Pavić, »'Sveto' u mreži dijalektike svjetovnosti«, Filozofska istraživanja 13 (1993) 3, str. 707-718, ovdje str. 707.

4

Daniel Bell, »The Return of the Sacred: The Argument About the Future of Religion«, Zygon: Journal of Religion and Science 13 (1978) 3, str. 187-208, ovdje str. 189-190, doi: https://doi.org/10.1111/j.1467-9744.1978. tb00334.x.

Ibid., str. 190

Usp. Marko Pranjić (ur.), Religijskopedagoško-katehetski leksikon, Katehetski salezijanski centar, Zagreb 1991., str. 634.

Usp. Vlaho Kovačević, Goran Kardum, Krunoslav Malenica, »Kvalitativno narativno istraživanje dječje religioznosti u kontekstu pet dimenzija religioznosti«, Bogoslovska smotra 89 (2019) 4, str. 885-898, ovdje str. 885.

Usp. M. Pranjić, Religijskopedagoško-katehetski leksikon, str. 634

D. Bell, »The Return of the Sacred«, str 187-208.
10

Ibid., str. 187

11

Usp. Jean-Jacques Wunenburger, Le sacré, Presses Universitaires de France, Pariz 2010. str. 82 .

12

Usp. Johan Huizinga, Le déclin du Moyen Âge, prev. Julia Bastin, Payot, Pariz 1967., str. 193.

13

Romano Guardini, L'esprit de la liturgie, Plon, Pariz 1929., str. 56-57.

14

Usp. J.-J. Wunenburger, Le sacré, str. 82.

15

Ibid.

16

Usp. Henri Avron, Ludwig Feuerbach ou la transformation du sacré, Presses Universitaires de France, Pariz 1957., str. 159.

17

Usp. J.-J. Wunenburger, Le sacré, str. 83.

18

Ibid.

19

Ibid. 
Religija se, nadalje, osporava zbog izdaje Svetog od strane svećenika koji održavaju lakovjernost i praznovjerje ili od strane Crkve koja izobličuje Objavu da bi tako podučavala ljude. ${ }^{20}$

»Nietzscheansko odbacivanje svećenika, prototipa bolesnih i dekadentnih bića, nedvojbeno sačinjava izraz jedne uvijek aktualne antiklerikalne tradicije, za što je primjer njena silina. $\ll^{21}$

Reformacijski pokret u XVI. stoljeću, koji je pokrenula Lutherova kritika papinskog autoriteta i prodaje oprosta grijeha, uvodi dugu tradiciju protestantskog intelektualizma i subjektivizacije religioznog, koji propovijeda čisto interpersonalni kontakt između Boga i čovjeka (pijetizam P. J. Spenera, J. Arndta, J. Gebhardta ili kasnije kod E. Troeltscha). ${ }^{22}$ Reakcija protureformacije ponovno je pojačala svećenički imperijalizam i teološku dogmatiku.

»S Lutherom je jamstvo religijskog vjerovanja premješteno iz onostranosti u unutarnjost subjektivnosti i time određeno kao nešto, što je u konačnici postavljeno djelatnošću samog subjekta. Prosvjetiteljstvo je, pak, religiju lišilo svake spoznajne vjerodostojnosti i tako spoznajne vjerodajnice predalo umu, glavnom organ(on)u probuđenog subjekta, a Deklaracija o pravima čovjeka supstancijalnu osnovu države vidjela je u načelu slobodne (umski posredovane) volje shvaćene u suprotstavljenosti povijesno zatečenim ili tradicijski zajamčenim pravima. $\$^{23}$

Libertinci i kasniji sljedbenici slobodoumlja od XVI. stoljeća pokreću sistematski proces protiv temelja religioznog mišljenja koje podupire neznanje, praznovjerje, ovisnost i podređenost razuma mističnom mišljenju. U stoljeću prosvjetiteljstva, kritika običaja, tradicije, pokornosti dogmi postaje obavezan put koji bi čovjeku omogućio pristup racionalnoj autonomiji. ${ }^{24}$

»Teolozi sekularizacije, nadasve protestanti, žele učiniti kraj prikazivanju transcendentnog i odvojenog Boga tako da postaje sudionikom u konkretnoj inkarnaciji povijesnog čovječanstva. Time žele rehabilitirati živu vjeru protiv svake crkvene institucionalizacije i dogmatske interpretativnosti svetih tekstova (K. Barth, D. Bonhoeffer, P. Tillich). Pojam sekularizacije našao se u središtu zanimanja radikalne teologije koja oslobađa vjeru od religije, i božansko od svetog $\mathrm{i}$ zagrobnog (P. Berger, F. Gogarten, H. Küng, J.-B. Metz, K. Rahner, C. Troisfontaines itd.).« ${ }^{25}$

Liberalizacijom vjerovanja u protestantskim Crkvama, sekularizacijom se tumači Božja odsutnost kao način njegova očitovanja. ${ }^{26}$ Rudolf Bultmann, poput Karla Bartha, Dietricha Bonhoeffera i Paula Tillicha pokušava promijeniti i odbaciti sve što priječi čovjekov osobni susret s Božjom riječju i njegovo predanje u vjeri, da bi Bog postao sudionikom u konkretnoj inkarnaciji povijesnog čovječanstva i rehabilitirao živu vjeru protiv svake crkvene institucionalizacije i dogmatske interpretativnosti svetih tekstova. ${ }^{27} \mathrm{Kršćanska} \mathrm{kerigma}$ mora u sebi biti oslobođena mitskog da bi pogodila suvremenog čovjeka i tako ga spasila.

»Razvoj biblijske egzegeze i povijesnih istraživanja o svetim tekstovima paralelno stvara teologiju demitologizacije, primjerice kod Rudolfa Bultmanna, koji želi ogoljeti Novi zavjet od njegova mitskog jezika, da bi dobio samo pročišćeni intelektualni smisao. $\ll^{28}$

Metoda koju je zastupao u njegovu rješavanju nazvao je demitologizacijom. ${ }^{29}$ Barth je Bultmannu predbacio da Objavu gleda antropocentrički, dok su mu drugi predbacili da je Objavu shvatio na gnostički način jer je Objavu, umjesto na otkupljenje kroz Isusovu osobu, postavio u otkupljenje kroz naviještanje Krista. ${ }^{30}$

Dietrich Bonhoeffer ide korak dalje od Bartha utoliko što je sa stajališta Objave pokušao shvatiti ne samo resakralizaciju nego i desakralizaciju. Bonhoeffer smatra desakralizaciju i sekularizaciju kao legitimne procese koji nam otkrivaju pravu sliku objavljenog Boga. Zato desakralizacija i sekularizacija 
podrazumijevaju legalnu autonomiju čovjekovih povijesnih uvjeta i njegove zauzetosti na području svjetovnoga.

»Proces sekularizacije i desakralizacije omogućuje susret Boga i čovjeka u čitavoj stvarnosti, a ne samo unutar nekog sakralnog prostora. Tako sekularizacija i desakralizacija osim negativnih elemenata imaju za kršćane jedan izazov i predstavljaju znak ovog vremena po kojem se bolje shvaća Božja riječ u ovoj povijesnoj stvarnosti. « ${ }^{31}$

Sekularizacija postaje poželjan kontekst novog odnosa s Apsolutom, dok nas Sveto uči da

»... mit i logos ne smiju se dakle nikad poistovjetiti, ali ni potpuno odvajati. U toku povijesti, pa i danas, čine se međutim uvijek takve greške. [...] Jedno i drugo vodi otuđenju čovjeka i prije ili kasnije izbije kao protest protiv predstavnika te jednostranosti. [...] Taj proces je tako naravno završio u sekularizaciji, desakralizaciji i ateizmu našeg vremena. « ${ }^{32}$

Zato su sekularizacija i desakralizacija povijesno određeni procesi koji životne stvarnosti ne gledaju na sakralan način. Kroz proces demitizacije, sekularizacija i desakralizacija žele racionalizirati sve religiozne stvarnosti i podvrgnuti ih, dakle, samo razumu..$^{33}$

Opčinjenost arhaičnom sakralnošću, koju su indirektno prenijeli znanstveni radovi iz etnologije, pokazuje kako desakralizacija počiva na moralnom i humanističkom gnjevu naspram okrutnosti, iracionalizmu i netoleranciji kod nekih primitivnih religija.

»Sveto ${ }^{34}$ je smatrano odgovornim za povijesnu imobilnost (l'immobilisme historique), čak i za socijalni konzervativizam tradicionalnih društava, za razvoj fanatičnih teokracija, za određene oblike totalitarizma koji guše autonomiju cjelokupnog privatnog života, za obrede koji krše čovjekova prava (kanibalizam, ljudske žrtve, spolna sakaćenja). Sveto je dakle smatrano ne-

20

Usp. ibid., str. 84.

21

Ibid.

22

Usp. ibid.

23

Zdenko Zeman, »Antinomije moderne. Filozofijske i sociologijske refleksije», u: Ivan Rogić, Zdenko Zeman (ur.), Privatizacija $i$ modernizacija, Institut društvenih znanosti Ivo Pilar, Zagreb 1998., str. 11-34, str. 16.

24

Usp. J.-J. Wunenburger, Le sacré, str. 84.

25

Ibid., str. 84-85.

26

Usp. Aldo Starić et al. (ur.), Enciklopedijski teološki rječnik: Sveto pismo, duhovnost, fundamentalna teologija, dogmatika, moral, ekumenizam, religije, Kršćanska sadašnjost, Zagreb 2009., str. 1019.

27

Usp. J.-J. Wunenburger, Le sacré, str. 84-85. 28 Ibid.

\section{9}

Usp. Rudolf Bultmann, Neues Testament und Mythologie. Das Problem der Entmythologisierung der neutestamentlichen Verkündigung, Chr. Kaiser, München 1985.; usp. Rudolf Bultmann, Der Begriff der Offenbarung im Neuen Testament, Mohr, Tübingen 1929.

30

Usp. Tomislav Ivančić, Otajstvo kršćanske objave. Teologija objave, Novi koraci, Zagreb 1993., str. 59.

31

Tomislav Ivančić, Kršćanstvo u traganju za identitetom, Kršćanska sadašnjost, Zagreb 1990., str. 46.

32

Ibid., str. $45-46$.

33

Usp. ibid., str. 46.

34

Pojam Sveto u ovom slučaju nije pisano u kurzivu jer se poštivalo jezično i pravopisno pravilo citiranog autora. Isti će se način citiranja provoditi kroz cijeli rad, iako autor ovog rada naziv Sveto piše u kurzivu. 
kompatibilnim s poštovanjem čovjekovih prava i s postojanjem društva u kojem bi pojedinac zaista bio samodostatan. $\ll^{35}$

Razumijevanje je religije u antropocentričnoj kritici, kao drugi oblik kritike,

»... nadahnuto agnosticizmom, prihvaća sveto ${ }^{36}$ kao produkt svojstven čovjeku, kao prikladan imaginarij, ali kojemu nužno ne pripada ontološka i natprirodna stvarnost. Religija i sveto otkrivaju antropološke strukture i osiguravaju sociološke ili psihološke funkcije. « ${ }^{37}$

Ako religija i Sveto otkrivaju antropološke strukture, kao integralni dio kulture, onda osiguravaju sociološke ili psihološke funkcije, ${ }^{38} \mathrm{~s}$ čime će se složiti mnogi sociolozi, izuzev Durkheima. Naime, za njega Sveto izražava, prije svega, dinamičnost zajedničkog života.

»Nadalje, desakralizacija religija Knjige očitija je više teologu nego etnografu ili onima koji se bave komparativnim religijama. Raskoli među religijama ili vjeroispovijestima uvijek su mnogo manji u izrazu svetosti nego u izrazu dogmi. $\aleph^{39}$

Desakralizacija, sekularizacija i sakralizacija kao misaoni okviri, ali i povijesna razdoblja prijelaza od kozmocentričnog na antropocentrično mišljenje i obrnuto, izmjenjuju se ili su čak i istodobno postojala.

»Kršćanstvo, u svakom slučaju, za mnoge povjesničare pokazuje mogućnost sinkretizma velikih religija. Kao što je islam znao očuvati staru predislamsku tradiciju, koja je preživjela putem ruralnog svetog (talismani, proročki snovi, marabutski kult nadasve u sjevernoj Africi), tako je kršćanstvo, po M. Eliadeu, integriralo nasljeđe neolitske agrarne Europe. Čak i više, ovaj kapacitet asimilacije različitih oblika svetosti može biti interpretiran kao pravi razlog uspjeha i ekspanzije neke religije. Čini se da se kod kršćanstva, ispod prividnog konflikta s antičkom kulturom, zapravo skriva neosporiv kontinuitet. $\ll^{40}$

Samim time, prijepornim ostaje pitanje: znači li za teologe sekularizacije određeni povijesni proces sekularizacije neko krivotvorenje i neki gnostički nadomjestak za izvorne kršćanske sadržaje ili je pak sam taj proces sekularizacije daljnji utjecaj koji su istim omogućeni tim izvornim kršćanskim sadržajima.

»Posebice na području reformatorskog vjerskog stava, koji je kao srastanje s društvenopolitičkom kulturom djelovanja i sa znanstvenom kulturom mišljenja uslijedio neposredno nakon ranog kršćanstva, moglo se kao sekularizaciju izvornog kršćanstva u radikalnijem smislu kritizirati njegov izlazak u svijet i povijest (Overbeck; S. Kierkergaard). « ${ }^{41}$

»Čini se da je kršćanstvo više od islama ili judaizma doprinijelo aktivnoj sekularizaciji, pa i samom njegovom povlačenju iz kulture. Čak i prije negoli se susrelo, počevši od renesanse, s razvojem znanosti i tehnologije, kršćanstvo je poznavalo forme svladavanja i uniformiranja svojih simboličkih temelja. H. Corbin i G. Durand naglašavaju da se kršćanska misao, počevši od 13. stoljeća, odlučno opredjeljivala za aristotelovsku logiku, nadasve preko intelektualnog nasljeđa Averroesa, odričući se, počevši od tada, neoplatonske tradicije Avicene koja je bila očuvana u islamskoj kulturi. Ova 'istinska metafizička katastrofa' rezultirala je padom simboličkih medijacija svetog i racionalizacijom i historicizacijom svetog. « ${ }^{42}$

Naposljetku, postoje oblici koji poprimaju čin samog nazadovanja Svetog, što je posebno izraženo u zapadnom modernitetu. Prividna desakralizacija socijalnih i kulturnih fenomena dovela je do toga da je gotovo svaki sociolog od kraja XIX. do sredine XX. stoljeća, ako izuzmemo Maxa Schelera i nekolicinu drugih, očekivao da će religija nestati početkom XXI. stoljeća. ${ }^{43}$

Navedeno uvjerenje više nije počivalo na razumu, sada se temeljilo na ideji racionalizacije kroz promjene u društvenoj strukturi čiji su razlozi tehnološki i ekonomski, a glavni kriterij je djelotvornost. Slijedeći Webera, asketski protestantizam, naročito u verziji kalvinizma, stvorio je asketsku etiku koja je racionalna, kontrolirana, pragmatična i antiemocionalna jer su ljudi obliko- 
vani većinom s institucijama u kojima žive. Svijet je postao, po zastrašujućoj frazi Maxa Webera, »željezni kavez « ${ }^{44}$ unutar racionalne organizacije društva. Time je stvoreno racionalističko, a ne racionalno gledanje na svijet, čime se opravdava takvo ponašanje unutar sveobuhvatne ideologije racionalizma. Dakle, $\mathrm{s}$ jedne se strane oštro suprotstavlja religiji, a s druge strane, sinkretizam je kroz promjene u kulturi trivijalizirao kulturu kroz dominantniji trend nevjerovanja.

»To je ideja da je svijet izgubio mističnost, da ljudi, a ne bogovi, vladaju svijetom, ili da izvan ovoga (s one strane) ništa drugo ne postoji, samo praznina, ukazujući na temeljnu misao modernizma, nihilizam. $\ll^{45}$

Weber je to nazvao Entzauberung (raščaranost). Razlozi raščaranosti ${ }^{46}$ počivaju na donekle autonomnim tendencijama kulture Zapada, ${ }^{47}$ no ne mogu zahvatiti tu situaciju autonomne tendencije kulture do kraja jer se radi o religijsko-povijesnom procesu racionalizacije, što ga nosi i potiče povijest religije. ${ }^{48}$ Po Hegelovu mišljenju, povijest ima telos (cilj, svrhu) i unutar njega čovjek realizira svoj marche générale ljudske svijesti koja uklanja magle iluzije i omogućava ljudima da jasnije vide svijet. ${ }^{49} \mathrm{U}$ tom smislu, povijesnost i čovjekova povijesna svijest važni su za razumijevanje povezanosti društva i religije sa značenjem sekularizacije religije. Značenja sekularizacije religije, kao što smo istaknuli u uvodu, razlikuju različite procese institucionalnih promjena. Odatle napetosti između sociologije i filozofije, a one u sociologiji religije polaze od factuma religijskih zajednica i različitih društveno-povijesnih značenja, dok

»... filozofija religije uvijek iznova nastoji aktualizirati 'zajednički telos' svih religija i smisao vjerničke (hodočasničke) egzistencije. Drugim riječima, sociologija religije ne može u svom institucionalnom usmjerenju zahvatiti 'temelj' vjere, već samo njezine pojavne oblike, koji se uvijek sagledavaju s obzirom na postojeći društveno-povijesni kontekst i na trenutačne 'potrebe vremena'. Ona stoga nužno ostaje zapletena u aporije dijalektike povijesnog razvoja religijâ kao institucija. $\ll^{50}$

35

J.-J. Wunenburger, Le sacré, str. 85.

36

Vidi bilješku 34.

37

J.-J. Wunenburger, Le sacré, str. 86.

38

Usp. ibid.

39

Ibid., str. 98.

40

Ibid.

41

Alois Halder, Filozofijski rječnik, prev. Ante Sesar, Naklada Jurčić, Zagreb 2008., str. 322.

42

J.-J. Wunenburger, Le sacré, str. 100-101.

43

Usp. D. Bell, »The Return of the Sacred«, str. 188.
44

Ibid.

45

Ibid., str. 189-190.

46

Usp. Max Weber, Wissenschaft als Beruf, Philipp Reclam, Stuttgart 1995., str. 19.

47

Usp. D. Bell, »The Return of the Sacred«, str. 190.

48

Usp. Max Weber, Ein Lebensbild, Mohr-Siebeck, Tübingen 1926., str. 348-350.

49

Usp. D. Bell, »The Return of the Sacred«, str. 187-188.

50

Ž. Pavić, »'Sveto' u mreži dijalektike svjetovnosti «, str. 708. 
Te napetosti ne nastaju samo zbog potrebe za autonomijom svjetovnih vrijednosti (društva, države, prava, filozofije, kulture, umjetnosti i znanosti) od eklezijalnog utjecaja (od početka XIII. do XVIII. stoljeća) nego u XIX. i XX. stoljeću idu za radikalnim posvjetovljavanjem društva, odnosno za potpunim uklanjanjem Svetoga iz ljudskog života i društva. Time će tijekom XIX. stoljeća pojam sekularizacije izgubiti svoju pretežno političko-pravnu oznaku, koja nužno ostaje zapletena $\mathrm{u}$ aporije dijalektike povijesnog razvoja religija kao institucija, a dobiti kulturološku, koja je zacijelo mnogo općenitija i bliža današnjim vlastitostima toga naziva.

Pojam sekularizacije sada podrazumijeva oslobođenje kulture i školstva od utjecaja religije. ${ }^{51}$ Svi interpretatori Svetog slažu se da je zapadno društvo od XVIII. stoljeća ušlo, na progresivan način, u razdoblje »laicizacije« svojih struktura i svojeg ponašanja kroz zahtjev za ostvarenjem laičke države.

»Posljedice laicizacije ponašanja bile su: 1) razne Crkve izgubile su kontrolu nad određenim brojem političkih, obrazovnih ili institucija socijalne pomoći i 2) došlo je do zahtjeva za nereligioznim normama u ponašanjima, primjerice kod seksualne etike. $\ll^{52}$

Taj dvostruki pokret širenja sfere civilnog društva, koji ne pripada Svetome, i unutarnje slabljenje religiozne sfere postaje, nadalje, predmetom suprotstavljenog tradicionalnog i progresivnog stajališta. Iako su suprotni, tradicionalno i progresivno stajalište podudaraju se u priznavanju historicizacije Svetog i njegove hegemonije kao gotove stvari. Jedno drugo stajalište, više sociološke i strukturalne naravi, odbacuje svu moralnu osudu i izvršavanje svake teološke procjene Svetog i njegovih kulturnih transformacija. ${ }^{53}$

»Sociolog u procesu laicizacije i sekularizacije ne vidi ni kraj ni obnovu svetog nego jednostavne zamjene. $\ll^{54}$

Suvremeni svijet odbacio je sigurno mnogo formi religijskog izraza, ali u isto vrijeme osigurava transfer Svetog na nešto drugo osim bogova (É. Durkheim, J. Duvignaud). ${ }^{55}$

»Sociologija time očito i namjerno preskače teologijsku prilagodbu i nadovezuje se na svoje zlatno razdoblje iz konca XIX. i početka XX. stoljeća.« $\ll^{56}$

Otuda potreba za uviđanjem granica sekularizacije, odnosno stanovite relativizacije, ma koliko god teorija sekularizacije bila misaono superiornija. Tako da se više ne ponovi apsurdna činjenica da je, upravo u ime načela vjerskih sloboda svih članova društva, vjernicima uskraćeno promicanje vlastitih načela u javnom životu - kako u svakodnevnom životu, tako i unutar društva u cjelini. Zato kršćanin ne može biti odgovoran građanin - sve dok ne počne kao vjernik oblikovati društvo i kritički o njemu promišljati. ${ }^{57}$ Odatle potreba da se sekularizacija, koja već dugo prožima društvo i kulturu upravo na ovaj način, promatra na temelju novih odnosa religioznog i svjetovnog. ${ }^{58}$

Time ne želimo odustati od duhovnog zahvaćanja vlastitog života i staviti na mjesto Svetog propisane ugovorne odnose između izvoditelja uloga, držanja društva na okupu kroz društvenu integraciju vrijednosnog konsenzusa, kao i prisilu, političku manipulaciju i pragmatičku suradnju. U suprotnom, religija se nakon završetka procesa socijetalizacije povlači u privatnu sferu - bez ikakva utjecaja na funkcioniranje društvenog sistema. Stoga se religija kao socijalna ili kulturna zajednica nalazi pred neizbježnom dilemom. U našem ulogama određenom svijetu religija kao posebna funkcija socijalne ili kulturne zajednice pada u kušnju građanske i političke religije i prilagođava se 
silama racionalizacije i socijetalizacije - kako bi imala bilo kakav utjecaj u modernome svijetu, čime potkopava vlastiti razlog postojanja. ${ }^{59}$

»Pri tom se ne čini usluga religijskom iskustvu građanske i političke religije - zatvarajući ga u vlastite mitove iz kojih je ono često barem dijelom samo proisteklo, a potom i druge mitove stvorilo. $\ll^{60}$

To je iskustvo,

»... prvo, idealizacija prošlosti, od koje se uvijek polazi da bi se istakao utjecaj religije; drugo, nedokazana pretpostavka o istovrsnosti religijskog ponašanja; treće, izjednačavanje religioznosti i crkvena postupka opravdanja vlastite prihvatljivosti u društvu. « ${ }^{61}$

»Samim time ne može se slijediti kriterij psihološke činjenice da je život pojedinca određen isključivo egom, prisilom, moći i političkim manipulacijama kao i pragmatičkim svrhama - već možda i u većoj mjeri transcendentnim autoritetom. « $^{62}$

Zato je potrebno u srži prepoznati što je u religioznom iskustvu istinito, a što je otuđujuće i daleko od realnosti ili duhovne jezgre Svetoga - tako da to možda otežava istinsko približavanje i dijalog među vjernicama i uopće ljudima. ${ }^{63}$ Taj odnos nije funkcionalan nego interpersonalan.

Sociološko razumijevanje teorije sekularizacije, koja je, sa svoje strane, uklopljena u još širu teoriju modernizacije društva, višeznačan je, složen i sveobuhvatni proces čitavog niza međusobno povezanih različitih društvenih promjena. Jedan od važnih društvenih i kulturnih konteksta sociološkog shvaćanja religije, samim time i sekularizacije, jest taj da je sociologija »utemeljena $\mathrm{u}$ razdoblju snažnih tenzija između religije i liberalne kulture Europe «. ${ }^{64} \mathrm{Na}$ taj se način religija može promatrati unutar dijalektički i društveno povijesnih tenzija između crkvenog autoriteta i novog ustroja liberalne kulture Europe, u nastojanjima koja su se ogledala na trima zasebnim razinama. To su: evolucijski svjetonazor, borba oko statusa moći i sukob koji je proizašao na temelju razuma i znanosti. ${ }^{65}$

51

Usp. Jakov Jukić, Lica i maske svetoga: ogledi iz društvene religiologije, Kršćanska sadašnjost, Zagreb 1997., str. 182.

52

J.-J. Wunenburger, Le sacré, str. 90.

53

Usp. ibid., str. 92.

54

Ibid., str. 92-93.

55

Usp. ibid., str. 93.

56

J. Jukić, Lica i maske svetoga, str. 185.

57

Usp. Ante Crnčević, »Osobna vjera i sekularizirani liturgijski čini«, Živo vrelo 27 (2010) 10 , str. 1.

58

Usp. V. Kovačević, Sekularizacija, modernitet $i$ katolički ethos, str. III.
59

Usp. ibid., str. III-IV.

60

Ibid., str. IV.

61

J. Jukić, Lica i maske svetoga, str. 210.

62

V. Kovačević, Sekularizacija, modernitet i katolički ethos, str. IV.

63

Usp. Ivan Supičić, Za univerzalni humanizam: prema potpunijoj čovječnosti, Kršćanska sadašnjost, Zagreb 2010., str. 87.

64

Jeffrey K. Hadden, »Toward Desacralizing Secularization Theory«, Social Forces 65 (1987) 3, str. 587-611, ovdje str. 589, doi: https://doi.org/10.1093/sf/65.3.587.

65

Usp. ibid. 
Prvi izvor tenzija bio je evolucijski svjetonazor unutar povijesne i filozofske misli koja je obilovala novim teorijama. One su postulirale razvoj svijeta $u$ sljedovima progresivnih faza, a takve su perspektive postulirale da je religija arhaični oblik koji stoji kao prepreka progresu. Dakle, osporavano je etablirano religijsko značenje povijesti. ${ }^{66}$ Drugi izvor dubokog razdora uključivao je borbu oko statusa $i$ moći nakon protureformacije i za vrijeme razdoblja stvaranja novih nacionalnih država. Iako je Francuska revolucija pridonijela slabljenju crkvene vlasti i moći, ona je ipak uspjela zadržati značajnu autonomiju i legitimizirati monarhiju. ${ }^{67}$ Treći izvor sukoba pobijao je pravo religije na monopolsko shvaćanje funkcioniranja uma i ljudske svijesti. Nastao je na temelju razuma i znanosti kao novog modela svijesti koji se počeo javljati. ${ }^{68}$

»Očito je da um nije poput ptice izmorene između anđeoskih i đavolskih sila.« ${ }^{69}$

Spomenuta povijesnost i čovjekova povijesna svijest važne su za razumijevanje teorije sekularizacije unutar društveno-kulturnog konteksta.

»Frank Miller Turner dobro opisuje tenziju i kulturalnu dilemu intelektualaca kasnog 19. i ranog 20. stoljeća koji su znali: '[...] da su prerasli crkvu kakvu predstavlja primjer kršćanstva, ali koji nisu zbog toga dovedeni do poricanja činjenice da je imati religijski stav prema životu isto toliko temeljan kao i vjerovanje u vjerodostojnost znanosti'. ${ }^{70}$

Auguste Comte smatra se začetnikom teorijskog utemeljenja procesa sekularizacije. Razlog tomu jest u njegovu postuliranju tri stupnja društvenog razvoja: teološki, metafizički i pozitivistički stadij. Comte je uočio društveni značaj religije, zbog čega nije mogao zamisliti prijelaz u društvo bez nje. Zaokupljen položajem religije u novome društvenom poretku, smatrao je potrebnim »ponovno izmisliti« sekularne oblike religije. ${ }^{71}$

Navedeno pokazuje kako je povijesni kontekst zapadnoga nasljeđa prethodio vlastitom teorijskom oblikovanju sekularizacije. Poteškoće se javljaju u povijesnom tumačenju razvoja sekularizacije. Naime, opseg tumačenja kategorije sekularizacije seže od povijesti njena urušavanja pa sve do povijesti njene emancipacije.

»Tako postaje istodobno jasno da s primjenom toga pojma ulazi u većinu slučajeva i decidirana pristranost u sporu oko položaja kršćanstva, odnosno crkava u modernom društvu. $\ll^{72}$

Dakle, nužno ostajemo u okviru kontingentne povijesti kršćanstva i njegove teleologije unutar dijalektike svjetovnog razumijevanja Svetog, povijesno mijenjajućih, različitih, vremenu (ali ne i Svetom) primjerenih oblika religioznosti. ${ }^{73}$ Prema tome, govor o novovjekovnom procesu sekularizacije $» i d e$ na štetu življenja svetoga, a u korist razmišljanja o svetome«. ${ }^{74}$ To traži, s jedne strane, definiciju sekularizacije religije u njenom isključujućem preciziranju unutar ljudskoga povijesnoga, konkretnoga svijeta, bez ikakvih trajnijih, ontologijskih ljudskih značajki, a s druge strane, razumijevanje bîti religije, zahvaćajući njene neponovljive osobnosti među drugim društvenim pojavama u procesu revitalizacije religije. ${ }^{75}$

»U potrazi za smirenjem zbog antinomija u životu i mišljenju i, nadasve, nastojanja da se domogne nekog višeg smisla - autentični intelektualci svjedoče izvornu vjeru, a ne njenu institucionalizaciju. ${ }^{76}$ 


\section{Slutnja prodora sekularizacije kod klasika sociologije}

Temelji za sustavnu formulaciju teorije o sekularizaciji nalaze se u radovima Émilea Durkheima i Maxa Webera, koji su otkrili da problem osobna postojanja u društvu ima »religiozno« značenje. Zato se, barem djelomično, odvajaju od pozitivističke i prosvjetiteljske kritike religije i utemeljuju njeno sociološko proučavanje. ${ }^{77}$ Durkheimovcima, s jedne strane, religija predstavlja niz zajedničkih predodžbi koje društvu pružaju moralno jedinstvo. Naime, po definiciji, odbacuju teoriju sekularizacije ili je se boje i vide je kao prijetnju tom jedinstvu. S druge strane, weberovcima je religija više supstantivno koncipirana kao struktura vjerovanja i običaja vezanih za spasenje. Dakle, sekularizaciju vide u društvenoj promjeni koja ta religijska značenja čini sve manje prihvatljivima. $^{78}$

Sveto je za Durkheima društveni proizvod, definiran postojanjem kolektivne svijesti, koja je izvan ljudi i nameće se posredstvom osjećaja dužnosti. Religija time doprinosi integraciji i održavanju društva, u čemu se očituje njezina stalna, nenadomjestiva funkcija »da nadživi sve pojedinačne simbole u koje se religijska misao redom zaodijevala «. ${ }^{79}$ Drugim riječima,

"... društvo se, dakle, prepoznaje u toj kolektivnoj sili koja se preko mitova može projicirati u individualiziranim oblicima ('mana', bogovi) i koja se preko obreda može čuvati i povremeno obnavljati. $\ll^{80}$

Durkheim je time ocrtao obrise svoga funkcionalističkog pristupa religiji. Naime, smatra da društvo koje ne osjeća potrebu da u pravilnim razmacima održava i jača kolektivna osjećanja i kolektivne ideje, koje tvore njegovo jedinstvo i osobitost, jednostavno ne može biti društvo. ${ }^{81}$ Stoga, religiozna snaga samo

66

Usp. ibid.

67

Usp. ibid.

68

Usp. ibid.

69

Ibid.

70

Ibid., str. 590 .

71

Usp. Ante Fiamengo, Saint-Simon i Auguste Comte, Naprijed, Zagreb 1987., str. 179.

\section{2}

Adel Theodor Khoury, Leksikon temeljnih religijskih pojmova: židovstvo, kršćanstvo $i$ islam, prev. Nedeljka Paravić et al., Prometej, Svjetska konferencija religija za mir, Zagreb 2005., str. 433.

73

Ž. Pavić, » 'Sveto' u mreži dijalektike svjetovnosti $\ll$, str. 708 .

74

Jakov Jukić, Budućnost religije: sveto u vremenu svjetovnosti, Matica hrvatska, Split 1991., str. 5.
75

Usp. Esad Ćimić, Iskušenja zajedništva, Did, Sarajevo 2005., str. 174-181.

76

Ibid., str. 181.

77

Usp. José Casanova, Public Religions in the Modern World, University of Chicago Press, Chicago - London 1994., str. 17.

78

Usp. Mark Chaves, „Secularization as Declining Religious Authority«, Social Forces 72 (1994) 3, str. 749-774, ovdje str. 750, doi: https://doi.org/10.1093/sf/72.3.749.

79

Emil Dirkem [Émile Durkheim], Elementarni oblici religijskog života: totemistički sistem u Australiji, prev. Aljoša Mimica, Prosveta, Beograd 1982., str. 387.

80

J.-J. Wunenburger, Le sacré, str. 86.

81

Usp. E. Dirkem [É. Durkheim], Elementarni oblici religijskog života, str. 387. 
je osjećaj koji kolektiv ulijeva svojim članovima, ali projicirana izvan svijesti koje ju doživljavaju i objektiviziraju. Da bi se objektivizirala, fiksira se na predmet, koji tako postaje svet jer je totemizam preteča i paradigma religije. ${ }^{82}$ Zahvaljujući svojoj religijskoj retorici i »obrednim svečanostima«, religija je vrlo često igrala ulogu »maske« $\mathrm{i}$ »pokrivala« ispod kojih su se odvijali scenariji nereligiozne ili potpuno svjetovne koristi. ${ }^{83}$

»Svetkovine i ceremonije omogućavaju regeneraciju društva preko svojih dvojnika koji su bogovi. S druge strane, energija svetog u religiji pronalazi samo jedan od svojih izraza: za Durkheima, kult Velikog bića Francuske revolucije kao sakralizacija političkog čovjeka primjer je avatara koji preko povijesti održava tu kolektivnu snagu. Mitovi i obredi miješaju se sa samom bîti društvenog. $\ll^{84}$

Durkheim u svojoj analizi suvremenog društva navodi kako je danas teško zamisliti od čega bi se ta slavlja i ceremonije mogle sastojati u budućnosti. Zaključuje da je to zbog toga što prolazimo kroz fazu prijelaza i moralne osrednjosti. Naime, velike stvari prošlosti, one koje su nadahnjivale naše očeve, ne pobuđuju u nama isti žar. Razlog tomu je što su do te mjere prešle u običnu naviku da ih više nismo niti svjesni, no i zbog toga što više niti ne odgovaraju našim današnjim težnjama. Pa ipak, još nije nastalo ništa što bi ih zamijenilo. ${ }^{85}$ Drugi tijek moderne sociologije religije teoriju sekularizacije pronalazi u utjecaju samoga kršćanstva (koji je zbog različitih razloga doprinio razočaranju svijeta i legitimaciji akcije $u$ autonomnim društvenim sferama) i racionalizaciji (procesu u kojem različite društvene sfere počinju djelovati svaka prema svojim standardima) svekolikog života. Vodeća je to slutnja o prodoru sekularizacije. Max Weber tvrdio je kako izvori nestanka čarolije zapadnog svijeta leže $u$ antičkom judaizmu. ${ }^{86}$

»Poput protestantizma, a u suprotnosti sa značajnim vjerama Azije, religija Izraela bila je ovosvjetovna. Teološki gledano, njezina ključna osobina bila je potpuno odbacivanje bilo kakvog oblika politeizma, a to je odbijanje imalo značajne društvene i kulturne posljedice. ${ }^{87}$

\section{Po Weberovu mišljenju,}

»... međusobno magično obuzdavanje bogova ili budalasti izrazi ljudske arogancije zamijenjeni su dužnošću da se bude poslušan Stvoritelju. Čuda se mogu izvoditi samo u Božje ime i samo uz Božju volju. Zlo je preseljeno iz područja mitologije u područje etike. Po Weberovu mišljenju, monoteizam je imao snažne posljedice. Oslobodio je čovječanstvo ovisnosti o mitologiji i magiji, dok nas je u isto vrijeme natjerao da se suočimo s brojnim etičkim dilemama. Duhovi su izbačeni iz svijeta prirode, koji je postao mjesto za ljudske pothvate u kontekstu služenja Bogu. « $^{88}$

Zato Weber temelje »raščaravanja svijeta« pronalazi u procesu racionalizacije (prosvjetiteljstvo), a početak u protestantskoj reformaciji. Racionalizacija, shvaćena u širokom smislu, uključuje promjene u načinu na koji ljudi razmišljaju i, posljedično, na koji djeluju.

»Prema tim poznatim pretpostavkama, u određenim društvima transcendentalno ukorijenjeni svjetonazori gube društveni i kulturni utjecaj kao rezultat dinamike racionalizacije (proces u kojem različite društvene sfere počinju djelovati svaka prema svojim standardima) i zbog sekularizacijskog utjecaja samog kršćanstva (koji je zbog različitih razloga doprinio razočaranju svijeta i legitimizaciji akcije $u$ autonomnim društvenim sferama). $\ll^{89}$

Prvobitni kapitalizam uspostavlja racionaliziranu etiku koja je proizvela obrazac kulturne raznolikosti, društvene diferencijacije i organizacijske specijalizacije. Religijska svijest usvaja otriježnjenu orijentaciju prihvaćanja svijeta, zajedno s birokratizacijom i urbanizacijom moderne svakodnevnice. ${ }^{90} \mathrm{~S}$ druge strane, zreli i razvijeni kapitalizam uskraćuje religijskim razlozima svako 
povjerenje. Po Weberovu mišljenju, sad svoje pouzdanje povjeravamo isključivo racionalnim razlozima. Time je religija izgubila zbiljski utjecaj na mišljenje, ponašanje i ustanove u životu ljudi. Društva kao što su bila zapadnjačka prije reformacije i revolucije s prvotno utjecajnim, ako ne i dominantnim, religijskim kulturama i institucijama postala su vrlo sekularna kroz općenit proces modernizacije. Weber je time ustanovio temeljne promjene društvene strukture i kulture u modernom svijetu, a one se očituju unutar gubitka religijskog utjecaja, što uključuje i okvir unutar kojeg je društvo ušlo u moderno doba. ${ }^{91}$ Zato se slutnja sekularizacije unutar Weberove analize religije kao teorija društvene promjene može identificirati u (institucionalnom ili kulturnom) religijskom utjecaju i aktivnosti u institucijskim ili kulturalnim sferama.

»Dakle, u pitanju je dvostruki proces. Jedan je sekularizacija, diferencijacija institucionalne vlasti u svijetu, koja je pojačana procesima racionalizacije. Drugi je, u sferi vjerovanja i kulture, raščaranost, ili ono što bih prije nazvao, zbog paralelizma pojma, profanacijom. $\ll^{92}$

Važno je naglasiti da se kod Maxa Webera pojam sekularizacija jedva mjestimice spominje, a na tim mjestima ne donosi današnje značenje pojma. ${ }^{93}$

»Poznato je da u njega prevladava izraz Entzauberung, koji bi se mogao shvatiti kao neka vrst razčaravanja. $\ll^{94}$

\section{Teorijske sinteze o sekularizaciji i sudbini religije}

U analizi procesa sekularizacije u svojoj knjizi Religija u sekularnom društvu, izdanoj prvi put 1966. godine kao esej o sekularizaciji, Bryan R. Wilson upućuje na zaključak da je sekularizacija logična, dosljedna i nužna posljedica racionalizacije života. ${ }^{95} \mathrm{Za}$ Wilsona, sekularizacija se odnosi na činjenicu da

82

Usp. J.-J. Wunenburger, Le sacré, str. 86.

83

Usp. Željko Mardešić, »Političke religije i novo mirotvorstvo«, Crkva u svijetu 33 (1988) 4, str. 408-415.

84

J.-J. Wunenburger, Le sacré, str. 87.

85

Usp. E. Dirkem [É. Durkheim], Elementarni oblici religijskog života, str. 387.

86

Usp. Max Weber, Ancient Judaism, Free Press, New York 1952.; Irving M. Zeitlin, Ancient Judaism: Biblical Criticism from Max Weber to the Present, Polity Press, Cambridge 1984.

87

Alan Aldridge, Religion in the Contemporary World: A Sociological Introduction, Polity Press, Cambridge - Malden 2006., str. 79. 88

Ibid., str. 79-80.

89

Frank J. Lechner, » The Case Against Secularization: A Rebuttal«, Social Forces 69 (1991)
4, str. 1103-1109, ovdje str. 1104, doi: https:// doi.org/10.1093/sf/69.4.1103.

90

Usp. Max Weber, Protestantska etika $i$ duh kapitalizma: odnos između religije i ekonomskog $i$ društvenog života u modernoj kulturi, prev. Dragutin Hlad, MISL, Zagreb 2006., str. $132-133$.

91

Usp. F. J. Lechner, »The Case Against Secularization $\ll$, str. 1105.

92

D. Bell, »The Return of the Sacred«, str. 190. 93

Usp. Max Weber, Wirtschaft und Gesellschaft: Grundriss der verstehenden Soziologie, Mohr, Tübingen 1964., str. 892.

94

J. Jukić, Lica i maske svetoga, str. 182. 95

Usp. Bryan R. Wilson, Religion in Secular Society: Sociological Comment, C. A. Watts, London 1966., str. 52. 
je religija viđena kao način razmišljanja. Naime, izvođenjem određenih praksi i institucionaliziranjem i organiziranjem tih obrazaca mišljenja i djelovanja religija gubi utjecaj na društvenoj, institucionalnoj i individualnoj razini, ${ }^{96}$ zbog čega i Crkve gube direktni utjecaj na ideje i aktivnosti ljudi. ${ }^{97}$ Premda »je društveni razvoj Zapada često prikazan kao glavni primjer smanjenja važnosti religijske svijesti u modernome svijetu «, ${ }^{98}$ ipak ne možemo zanemariti činjenicu kako je »religija u svojoj bogatoj raznolikosti, osnovna organizacijska i kulturalna komponenta svakog poznatog ljudskog društva «. ${ }^{99}$

»Univerzalnost religije ukazuje na alternativnu i jednako vjerojatnu hipotezu: slabljenje vezanosti za 'natprirodne' oblike objašnjenja, zajedno sa sve jačim oslanjanjem na 'tehnoracionalna' objašnjenja iskustva, predstavlja promjenu načina tumačenja 'svetog'. Očiti povijesni trendovi mogu se interpretirati kao promjena izražavanja religijske svijesti više nego degeneracije univerzalnog kulturnog oblika. [...] Bryan Wilson (1982.) prepoznaje, ali ne uzima u obzir tu alternativu u odnosu na tezu o sekularizaciji i ispravno zamjećuje da je ključna razlika između sukobljenih hipoteza u tumačenju same religije. «100

Taj spor oko definicija predstavlja značajni izvor napetosti u znanstvenim i sociološko-znanstvenim raspravama. Premda su danas ideološke tenzije primirene, ipak su vidljive razlike, doduše u nešto manjim omjerima, $u$ tumačenjima prednosti i nedostatka same religije. Wilson tvrdi da se pristalice teze o promjeni oslanjaju na »funkcionalističke« definicije koje naglašavaju kohezivni utjecaj religije u društvenim odnosima. No o tezi sekularizacije govori se da je utemeljena na »supstantivnim« definicijama religije koje naglašavaju upućivanje na spasenje i nad-empirijsko i imaju »slučajnu prednost što su u skladu s općom upotrebom «. ${ }^{101}$ Time linija razdvajanja postaje fluidnijom i uočavamo odmak od klasičnih interpretacija. Po Wilsonu, teza o sekularizaciji očituje se u slabljenju društvene važnosti religije, postulirajući temeljne promjene društvene strukture i kulture u modernom svijetu. Wilson nabraja sedam karakteristika sekularizacije koje bismo mogli sažeti u dvije opće kategorije: prva se kategorija odnosi na slabljenje uloge tradicionalnih religijskih ustanova u svakodnevnom životu i provođenje javne vlasti, dok bi se druga kategorija odnosila na smanjivanje važnosti brige o natprirodnome (»nad-empirijskome«) kao temelju moralnog poretka i povezano osnaživanje racionalne i empirijsko-moralne orijentacije. ${ }^{102}$

»Hipoteza je tipično formulirana u sljedećem obliku: svijest razvija manje praznovjernu osobnost i pojedinci izražavaju na manje očit način religijsko ponašanje kako ljudska društva prolaze kroz demografski, proizvodni i političko-legalni rast. « ${ }^{103}$

Za Petera Bergera, sekularizacija je višedimenzionalni proces koji ima nekoliko poznatih temeljnih uzroka: industrijalizacija, urbanizacija, racionalizacija i napredak znanosti. Ponavljajući tvrdnje ranijih društvenih mislilaca, uključujući Hegela, Schopenhauera, Nietzschea i Webera, Berger također smatra da je sama religija, paradoksalno, bila nenamjerni nositelj sekularizacije. ${ }^{104}$ Polazeći od toga da judeo-kršćanska tradicija sadržava elemente koji upravo dovode do sekularizacije, Bergerovo prvotno poimanje sekularizacije slično je Wilsonovu. No za razliku od Wilsona u analizi procesa sekularizacije, Berger pronalazi same temelje kršćanstva odnosno judaizma. Time je dao dva važna doprinosa sekularizacijskom pristupu.

Naime, Bergerov rani esej (1963.) o izraelskim prorocima bio je važan za lociranje početaka racionalnosti u monoteizmu Starog zavjeta. Takvim je pristupom doprinio tvrdnjama Webera, Ernsta Troeltscha, Roberta Mertona i Davida Martina da su judaizam, kršćanstvo i protestantizam razvili i potpomagali početke vlastitoga slabljenja. ${ }^{105}$ Nadalje, sekularizaciju Berger u rani- 
jim radovima definira kao »proces putem kojega se sektori društva i kulture oslobađaju dominacije vjerskih institucija i simbola «, ${ }^{106}$ pa je jedan tip religije bio centralan kod impliciranosti u modernizaciji i pomogao je stvoriti uvjete u kojima je veliki broj ljudi mogao početi živjeti bez puno ili bez religije uopće. ${ }^{107}$ Zbog toga što je društveno-povijesni kontekst obilježen pluralizmom, Berger razlog vidi u društvu koje je okarakterizirano tržištem svjetonazora, simultano u nadmetanju jedan s drugim. Stoga je otežano održavanje onoga u što smo sigurni jer ono nadilazi empirijske nužnosti društva i pojedinca za funkcioniranje. ${ }^{108}$ Čineći božansko djelovanje predvidljivim, dopustio se razvoj znanosti i tehnike i potpomagao rast kapitalizma pa se tako, pojednostavljujući natprirodno, dopustilo da ono što je drago Bogu postane kodificirano, rutinizirano i racionalizirano. ${ }^{109}$

Berger, nadalje, ističe kako su u tom društveno-povijesnom kontekstu Crkve prisiljene ući u sukob i doslovno se natjecati s drugim nositeljima "posljednjeg« značenja, kako bi privukle pažnju. Crkve nisu više nužni i neophodni posrednici integracije individuuma u društvo. Integracija se danas vrši posredstvom novih službenih modela industrijskog i postindustrijskoga društva: sredstvima javnoga priopćavanja, konzumerizmom, tehnikom i aktivnim sudjelovanjem u tehnostrukturama. Stoga je religija koja počiva na natprirodnim sigurnostima u pluralističkoj situaciji sekularizirajuća jer upada u krizu kredibiliteta. ${ }^{110}$

Zabrinut za društveni poredak i integraciju, Berger, kao i njegov suradnik Thomas Luckmann, naglašava kognitivnu dimenziju religije zbog toga što nam ona pruža misaone koncepte i kategorije kroz koje možemo naći značenje, a time i razumijevanje u postojećim životnim problemima. ${ }^{11}$ Potrebno je

96

Usp. ibid., str. 11.

97

Usp. ibid., str. 22.

98

Bryan R. Wilson, Religion in Sociological Perspective, Oxford University Press, Oxford 1982., str. 153-168.

99

Timothy Crippen, »)Old and New Gods in the Modern World: Toward a Theory of Religious Transformation«, Social Forces 67 (1988) 2, str. 316-336, ovdje str. 319-320, doi: https:// doi.org/10.1093/sf/67.2.316.

100

Ibid., str. 320 .

101

Ibid.

102

Usp. B. R. Wilson, Religion in Sociological Perspective, str. 153-168.

103

T. Crippen, »Old and New Gods in the Modern World «, str. 319.

104

Usp. Peter L. Berger, The Sacred Canapy:
Elements of a Sociological Theory of Religion, Doubleday and Company, New York 1967., str. 110-125.

105

Usp. Steve Bruce, God is Dead: Secularization in the West, Wiley-Blackwell, Malden 2002., str. 87-88.

106

P. L. Berger, The Sacred Canapy, str. 107.

107

Usp. S. Bruce, God is Dead, str. 87-88.

108

Usp. Steve Bruce, »The Curious Case of the Unnecessary Recantation: Berger and Secularization«, u: Linda Woodhead, Paul Heelas, David Martin (ur.), Peter Berger and the Study of Religion, Taylor \& Francis e-Library, New York 2002., str. 87-100.

109

Usp. S. Bruce, God is Dead, str. 87-88.

110

Usp. ibid., str. 88 .

111

Usp. A. Aldridge, Religion in the Contemporary World, str. 7 . 
napustiti određenje religije u njezinu institucionalnom obliku, a prihvatiti ju u njezinu antropološkom temelju, što je tipičan fenomenološki zaključak. ${ }^{12}$

Religijske ustanove nisu univerzalne nego samo njihovi arhetipski uvjeti postanka sa svim oblicima simboličke samo-transcendencije, koje Luckmann izjednačuje s religijom. Navedeni proces rezultat je »teze o sekularizaciji« i »teze o religijskoj promjeni«, koji nije, kao što su neki sociolozi brzopleto zaključili, iskorjenjivanje religije, nego se ona »zadovoljava« svojom zaslugom u slabljenju nekih specifičnih religijskih organizacija. Time Luckmannova sociologija stavlja funkciju religije iznad same religije, čime ostaje samo funkcija jer religije više nema. Samim time se sadržaj religije mijenja, a njezina funkcija ostaje ista. Za Thomasa Luckmanna, sekularizacija je zapravo samo prijelaz od jedne javne, službene i crkveno ustrojene religije na jednu privatnu religiju, još doduše društveno »nevidljivu«, ali koja će sigurno zavladati u modernom industrijskom društvu. ${ }^{113}$ Napuštajući određenje religije u njezinu institucionalnom funkcionalističkom obliku, a prihvaćajući je u njezinu antropološkom fenomenološkom temelju, Luckmann je negdje duboko u podtekstu pritajeni fenomenolog religije. ${ }^{114}$ Naime, on pojam sekularizacije koristi u opisu procesa koji dovode do povećane neovisnosti različitih odsječaka društvena ustroja i oslobađanja od pravila koja su imala podrijetlo u sakralnom svemiru. No zanimljivo je da ipak tim pojmom odbija označiti opći slijed razvoja religije u suvremenom društvu. ${ }^{115}$

Taj posvemašnji proces društvene deregulacije religije usredišten je na slabljenje ili čak nestajanje Svetoga kao ustanove. ${ }^{116}$ Tako postoji dvostruka razina jer promjene $u$ religiji proizlaze kao reakcija na promjene $u$ institucionalnom životu (kako bi ih opravdale ili napale), i kao promjene vezane uz promjene u moralnom temperamentu i senzibilitetu, uz ekspresivne stilove $\mathrm{i}$ oblike simbolizacije, uz uništavanje starih simbola i stvaranje novih. Po tom zaključku, Luckmanna mnogi smatraju simboličkim funkcionalistom.

»Općenito govoreći, revitalizacija i inovacija održavaju religiju, koja se opire nestajanju iznova mijenjajući svoje oblike. U biti, sekularno se svodi na one dijelove društva i kulture, koji su oslobođeni od pretpostavki nadnaravnog. «117

Po Steveu Bruceu, taj dominantni trend religijskih promjena u modernom svijetu, koji se može nazvati sekularizacijom, pokazuje da ne postoji jedna teorija sekularizacije, nego da postoje skupine opisa i objašnjenja koja su dovoljno dobro međusobno sukladna. ${ }^{118}$ Zato neki smatraju da je takozvana teza o sekularizaciji, u svakom slučaju kao paradigma, poprilično solidna struktura teorije s valjanim povijesnim sadržajem. ${ }^{119}$

Steve Bruce označava individualni odgovor ključnim elementom sekularizacijske paradigme. Zato kršćanstvo, koje proistječe i dobiva snagu od socijalne i konfesionalne zajednice, ima za posljedicu diferencijaciju i socijetalizaciju.

»Posljedica diferencijacije i socijetalizacije jest slabljenje uvjerljivosti bilo kakvog sveobuhvatnog moralnog i religijskog sustava, zamijenjenog s konkurirajućim koncepcijama, koje su, dok su možda imale puno toga za reći privatiziranom, individualnom iskustvu, jedva mogle biti povezane s izvršavanjem društvenih uloga ili s funkcioniranjem društvenih sustava. « ${ }^{120}$

Religijska tradicija kao rezultat reformacije ubrzala je razvoj religijski neutralne države upravo zbog toga što je razvoj uspješne ekonomije zahtijevao visok stupanj integracije: učinkovitu komunikaciju, zajedničke zakone kako bi se izvršavali ugovori, atmosferu povjerenja itd. Dakle, dolazi do potrebe 
integriranja nacionalne kulture, ${ }^{121}$ nove procjene i rekonstrukcije odgovarajućeg kršćanstva.

»Nadalje, gdje je postojao religijski konsenzus, postojala je mogućnost pobrinuti se za dominantnu religijsku tradiciju u kontekstu nacionalne 'visoke kulture'. Članovi svećenstva mogli su nastaviti biti učitelji, povjesničari, propagandisti, zaposlenici javne uprave i vojni stratezi. Tamo gdje je bilo malo konsenzusa, razvoj države najčešće je bio sekularan.«122

Perspektiva razvojnih procesa konfesionalnog kršćanstva u tijeku moderniziranja dovodi do "pocrkvenjivanja kršćanstva« ${ }^{123}$ što uključuje stvaranje Crkava kao klerikalnih organizacija unutar kršćanstva, a to se pretvara u katoličku supkulturu (potkulturu), koja više ne obilježava čitavo kršćanstvo, nego ponajčešće manjinski katolički dio puka povezuje s katolicizmom u nekoj vrsti pod-društva. Zato je kršćanstvo unutar Crkava, kao klerikalna organizacija, primorano pomiriti svoju vjeru s činjenicom da postoje različitosti. Dakle, potrebno je ograničiti vlastitu vjeru u određeni odjeljak društvenog života, gdje će teolozi, župnici ili redovnici kao 'religiozni specijalisti' (kler) nastupati prema laicima isključivo s duhovnim zahtjevom za vodstvo. Sociolog Niklas Luhmann zbog toga $\mathrm{u}$ institucionalnoj specijalizaciji Crkva $\mathrm{u}$ odnosu na strukturu društvenog sustava, $\mathrm{s}$ jedne strane, te u privatiziranju religioznih odluka, s druge strane, vidi bitne vidove sekularizacije. ${ }^{124}$ Tražeći Sveto unutar strukturalnih promjena društvenog sustava, a u vidu novih religijskih pokreta, sekularizacija bi se mogla definirati i kao »posljedični problem prijelaza iz stratificiranog u funkcionalni društveni ustroj, kojeg religijski sustav ne želi, ali prema kojem se mora uskladiti ${ }^{125}$ u uvjetima (post) modernog svijeta.

Karel Dobbelaere analizira proces sekularizacije kao multidimenzionalni koncept koji se odnosi na proces laicizacije, religijskih promjena i religijske involviranosti. Preciznije, sekularizacija upravo jest proces laicizacije, konceptualiziran kao proces diferencijacije, ali s vrlo složenim i različitim odno-

112

Usp. J. Jukić, Budućnost religije, str. 64. 113

Usp. Thomas Luckmann, The Invisible Religion: The Transformation of Symbols in Industrial Society, The MacMillan Company, New York 1967., str. 117.

114

Usp. J. Jukić, Budućnost religije, str. 64. 115

Usp. J. Jukić, Lica i maske svetoga, str. 204.

116

Usp. ibid., str. 216.

117

Esad Ćimić, »Religija kao integralni dio kulture «, Mediji, kultura i odnosi s javnošću 1 (2002) 1, str. 32-37, ovdje str. 36.

118

Usp. S. Bruce, God is Dead, str. 2.

119

Usp. F. J. Lechner, »The Case Against Secularization $\ll$, str. 1103.
120

S. Bruce, God is Dead, str. 13-14.

121

Usp. ibid., str. 14.

122

Ibid.

123

Usp. Franz-Xaver Kaufmann, Kirche begreifen: Analysen und Thesen zur gesellschaftlichen Verfassung des Christentums, Herder, Freiburg 1979., str. 100.

124

Usp. Niklas Luhmann, Funktion der Religion, Suhrkamp Verlag, Frankfurt 1977., str. 225-271.

125

Detlef Pollack, Religiöse Chiffrierung und soziologische Aufklärung. Die Religionstheorie Niklas Luhmanns im Rahmen ihrer systemtheoretischen Voraussetzungen, Verlag Peter Lang, Frankfurt 1988., str. 128. 
som spram procesa religijskih promjena i religijske involviranosti. ${ }^{126} \mathrm{Zbog}$ toga Dobbelaere razlaže dimenzije sekularizacije na tri razine. Prva je razina sekularizacije vezana uz društvenu razinu religije, a označava proces funkcionalne diferencijacije religije, odnosno proces razvoja religije u podsustav čime gubi svoju prijašnju dominantnu ulogu u društvu. Religijske promjene unutar druge razine sekularizacije vezane su uz promjenu društvenoga položaja religijskih organizacija (Crkvi, denominacija, sekti i novih religijskih pokreta). Treća razina kao individualna sekularizacija referira se na odnose između normi religijskih grupa i stavova njihovih članova. ${ }^{127}$ Te posljednje razine time proizlaze iz Weberova pristupa koji naglašava smanjivanje utjecaja religije na društveni život.

\section{Kritika sociologijskih teorija o sekularizaciji religije}

Provedena sociološka analiza sekularizacije osvijestila je središnje probleme koji proizlaze iz samorazumijevanja modernog društva i ljudi koji u njemu žive. Deregulacija današnje religioznosti izazvana je anomijom. »Teze o sekularizaciji« i »teze o religijskoj promjeni« unutar modernog društva traže potpunije objašnjenje. Socio-kognitivna objašnjenja znanstvenih promjena tvrde da je religija $i$ dalje prisutna u modernom društvu, uspostavljajući legitimnost socijalnog objašnjenja teorije sekularizacije u usporedni položaj s kognitivnim procjenama. One u procesu modernizacije i tehnicizacije znače napuknuće smisla, a za posljedicu imaju osjećaj ravnodušnosti, gubitak temelja, beskorisnost religije. ${ }^{128}$

Nedvojbeno, kako se napuknuće smisla očituje poplavom značenja »teze o sekularizaciji« $\mathrm{i} »$ teze o religijskoj promjeni« u kojoj se svijet nije samo, u poetskom smislu, odčaravao izvan krutih ograda konfesionalne socijalizacije vjernika unutar službene Crkve, nego je, kako pod pseudonimom Jakova Jukića primjećuje Željko Mardešić, postao »pustinja koja rađa pustinju« «129 pa je razlika između ateizma i sekularizacije i u tome što je on postao obična nevjera nevjernika, dok sekularizacija proizvodi nevjeru vjernika. ${ }^{130}$

»Središnji religiozni problem suvremenoga svijeta nije, dakle, ateizam nego vjerska ravnodušnost, praktični život bez misterija, navikavanje na potpunu svjetovnost i nekršćanstvo kršćana. $\ll^{131}$

Sekularizacija je počela prazniti svijet od značenja i svrhe. Na djelu je kriza smisla i iščezavanje senzibilnosti spram rubnih pitanja ljudske egzistencije, stvarajući duhovnu pustoš. ${ }^{132}$ Proces društvene deregulacije religije u prerušenom obliku smjestio se u pojam same sekularizacije u kojoj je svaki dublji smisao tiho zamirao, uvjetovan raspoloživim utjecajima i stvarnostima, nametnutim istodobno i od države i od vladajuće situacije (post)modernog stanja opterećenoga ideološkim općenitostima. Složenost i višedimenzionalnost sekularizacije - kontroverznost $\mathrm{u}$ raspravama oko sadržaja njezina određenja kao povijesnog procesa - sažeti su slikovito u tvrdnji koja »možda« zvuči paradoksalno, ali danas u sociologiji religije više znamo koliko je društvo sekularizirano (religiozno), nego što to znači da je sekularizirano (religiozno). ${ }^{133} \mathrm{Uz}$ spomenutu definiciju ide činjenica da primjena toga izraza ukida jednoznačno vrednovanje i stoga predstavlja slobodnu vrijednost.

»Pretpostavka da modernost neophodno vodi do opadanja vjere je u principu 'slobodna vrijednost'. To znači da je mogu potvrditi kako ljudi koji ovo smatraju dobrom viješću, tako i oni koji ovo smatraju vrlo lošom viješću. «134 
Sam pojam ne počiva ni na primjeni vrijednosnog predznaka ni na tumačenju gubitka religioznih veza, transcendentnih stavova u izrazu »posvjetovljenje«. U tom smislu, inovativna teza sekularizacije zato predlaže način prevladavanja idejno-političkog karaktera sekularizacije koja se izravno povezuje u apsolutnoj neovisnosti »religioznosti« o dijalektici društveno-povijesnih prilika. Navedeno pokazuje da pad društvene moći religije kao »progresivna autonomizacija društvenih dijelova od dominacije religijskih značenja i institucija« nisu prouzročili opći društveni procesi modernizacije. Modernizacija kao »višečinjenični pojam, koji obuhvaća industrijalizaciju rada; pomak od sela do mjesta i gradova; zamjenu malih zajednica društvom; uzdignuće individualizma; uzdignuće egalitarizma; i racionalizaciju misli i društvene organizacije $\aleph^{135}$ ima efekt sekularizacije, u nekim mjestima više nego u drugima. Modernizacija potiče i snažne pokrete protiv sekularizacije.

»Također, sekularizacija na društvenom nivou nije neophodno povezana sa sekularizacijom na nivou individualne svijesti. Neke su vjerske institucije izgubile moć i utjecaj u mnogim društvima, ali i stara i nova religijska vjerovanja i praksa nastavile su ipak postojati u životima pojedinaca, poprimajući ponekad nove institucionalne forme, a ponekad bi dolazilo do velike eksplozije žara. ${ }^{136}$

Nadalje, neke vjerske institucije odigrale su važne društvene i političke uloge. Zato prihvaćamo desekularizaciju kao drugu vrstu teorijskog pristupa problemu složenosti između religioznosti i modernosti, što pokazuje da je izbor paradigme sekularizacije istovremeno i socijalan i kognitivan. »Tragajući za određenim 'temeljnim nacrtom' ili 'dubinskom logikom', koji ravnaju životom cjeline modernoga društva «, ${ }^{137}$ takav pristup nazivamo (teorijama) modernosti. One, kao implicirana vjerovanja konkretne zajednice znanstvenika, po Kuhnovu mišljenju, mogu objasniti zašto se teorija sekularizacije mijenja onda kada to isključivo »racionalno « ne bi bilo opravdano, kao i to zašto se paradigma sekularizacije ne mijenja kada za to postoje svi »racionalni« razlozi. ${ }^{138}$ To pokazuje, kao što smo istaknuli, kako je teorija sekularizacije opte-

126

Usp. Karel Dobbelaere, „Secularization: A Multi-Dimensional Concept«, Current Sociology 29 (1981) 2, str. 3-153, ovdje str. 14, doi: https://doi.org/10.1177\% 2F001139218102900203.

127

Usp. Karel Dobbelaere, Secularization: An Analysis at Three Levels, Peter Lang, Bruxelles 2002., str. 24-25.

128

Usp. A. Starić (ur.), Enciklopedijski teološki rječnik, str. 1019.

129

J. Jukić, Lica i maske svetoga, str. 214. 130

E. Ćimić, Religija kao integralni dio kulture, str. 36 .

131

J. Jukić, Lica i maske svetoga, str. 192.

132

Usp. ibid., str. 214.
133

Usp. ibid., str. 191.

134

Piter L. Berger [Peter L. Berger], »Desekularizacija sveta: opšti pregled«, u: Piter L. Berger [Peter L. Berger] (ur.), Desekularizacija sveta: preporod religija i svetska politika, prev. Minja Janković, Mediterran Publishing, Novi Sad 2008., str. 11-30, ovdje str. 13.

135

S. Bruce, God is Dead, str. 2.

136

P. L. Berger, »Desekularizacija sveta«, str. 13.

137

Zdenko Zeman, Autonomija i odgođena apokalipsa: sociologijske teorije modernosti $i$ modernizacije, Hrvatska sveučilišna naklada, Zagreb 2004., str. 59.

138

Usp. Darko Polšek, Sociologija znanstvene spoznaje, Hrvatski kulturni dom, Rijeka 1995., str. 5. 
rećena idejno-političkim karakterom. Po Luckmannovu mišljenju, sekularizacija je »moderni mit «, ${ }^{139}$ a za neke sociologe fikcija, ideologijski pojam. ${ }^{140}$ Paradigmatski status društvenih znanosti sekularizaciju interpretira od početaka kao sastavni dio shvaćanja načina kako se odvijao proces modernizacije. Po mišljenju Jeffreyja K. Haddena,

")... status je sekularizacije bio toliko očit da je jedva sačinjavao problematično pitanje koje zahtijeva empirijsko istraživanje. Ukratko, sekularizacija nije samo bila uzeta zdravo za gotovo; ideja sekularizacije postala je sakralizirana. «141

Brojne činjenice, načini elaboracije globalne religijske scene i filozofski eros svjedoče o jednom procesu sekularizacije religije i religizacije sekularnog u postmodernoj duhovnosti, koji su na djelu i koji su nezaobilazni.

Posvjetovljenje i sekularizacija tijekom povijesti zadobili su hermeneutičku kategoriju idejno-političkog karaktera modernoga doba. Pojmom posvjetovljenja kršćanstvo upućuje na pretpovijest novog vijeka, a pojmom sekularizacije naglašava njegovo trajno značenje u razumijevanju općih društvenih procesa modernizacije društva (industrijalizacije, urbanizacije i širenja znanosti). Stoga je ovo emancipacijsko samopotvrđivanje čovjeka, koje moderna prikazuje kao novo doba, ${ }^{142}$ prikazano kao nepovratan proces koji se nastavlja u razmatranju o modernom svijetu i u duhu moderniteta kao nove ideologije. Rodney Stark, kao jedan od poznatijih kritičara teorija o sekularizaciji, navodi pet ključnih točaka koje se odnose na proročanstva o sekularizaciji. Prvo, ističe bitnu povezanost procesa modernizacije i sekularizacije, ali i nedokazanost kako je sekularizacija rezultat modernizacije, čime se uz određivanja same religije javljaju i prijepori oko određivanja moderniteta. Druga točka koju valja uočiti u proročanstvima o sekularizaciji jest to da ona ne ističu samo institucionalno diferenciranje i odvajanje Crkve od države, nego se bave opadanjem društvene važnosti religije i smanjivanjem religioznosti pojedinca. No to nije tako jer ne možemo izjednačiti religiju i religioznost, prepuštajući Sveto dijalektici svjetovnog, s obzirom na to da istina religije uvijek iznova ostaje onkraj ove pocijepanosti povijesnog duha. ${ }^{143}$ Treća stvar koju treba uočiti o tezi o sekularizaciji ističe znanost kao područje koje ima »najubojitije posljedice za religiju«. To se pokazalo pogrešnim. Četvrto, sekularizacija se smatra ireverzibilnim procesom, odnosno negira se mogućnost religijske revitalizacije, što se u većem dijelu istočne Europe pokazalo mogućim. Peto i posljednje, govori kako se rasprava o sekularizaciji uglavnom odnosi na kršćanstvo, a posljedice sekularizacije često primjenjuju globalno. ${ }^{144}$

Zato je Peter L. Berger 1974. godine

»... ponudio određeni broj razloga za sumnju u njegovu početnu sigurnost da suvremenost potkopava religiju. [...] S varirajućim razinama posvećenosti, Berger je ponudio sljedeće razloge za revidiranje njegova uvjerenja u tezu o sekularizaciji: a) rast konzervativnih i evangeličkih Crkava u Sjedinjenim Državama; b) slabljenje liberalnih Crkava; c) održavanje interesa za religiju (ako ne za odlazak u crkvu) u drugim zapadnjačkim društvima i d) vitalnost religije u drugim dijelovima svijeta. $\ll^{145}$

Stoga s Bergerom, jednim od rijetkih predstavnika sekularizacijske teorije koji je u svojim radovima priznao njene nedostatke, paradoksalno možemo reći da je današnji svijet masovno religiozan i jest sve drugo osim sekulariziranog svijeta, kakav je predviđen od strane velikog broja mislilaca i analitičara modernog doba. ${ }^{146}$ To ne znači da nemamo sluha za načine mišljenja koji još cvjetaju u zapadnoj Europi i međunarodnoj supkulturi koju čine visokoobrazovani lju- 
di, posebno u humanističkim i društvenim znanostima - a supkultura istinski je sekularizirana. ${ }^{147}$

»Vjerovanje u sekularizaciju održavano je zbog dubokog i trajnog antagonizma prema religijskom vjerovanju i različitim izrazima organizirane religije. «148

U tom smislu, sekularizacija je puno više doktrina, nego što je teorija. ${ }^{149}$ Zato nas ne iznenađuje zabrinutost za sudbinu tako shvaćene sekularizacije izvan duhovnog horizonta religioznosti. Jedini tračak nade vidimo u neodrživoj tezi teorije sekularizacije da modernizacija neophodno vodi opadanju religioznosti, kako u društvu, tako i u svijesti pojedinaca - odnosno da je suvremeni svijet sekulariziran. U zapadnoj Europi naglašavaju se kvalitativni pokazatelji sekularizacije - koji je pokazuju kao općedruštvenu pojavu za veću emancipaciju diskursa od religije i sadržaja religioznosti, kao i za mogućnost stvaranja temelja za razvoj vlastitog znanstvenog diskursa. Time ujedno nije otklonjeno tumačenje sekularizacije društva - teorijskim kategorijama ideologije i velikih sustava značenja. ${ }^{150}$ Nudeći drugi paket ideja, Mark Chaves pomaže pronaći način kako se snalaziti s često labirintnim pojmom sekularizacije. Pritom naglašava da je od prosvjetiteljstva većina beskrajnih rasprava o sekularizaciji bila o »religiji «, a da je morala biti o »religijskom autoritetu ${ }^{151}$ Što će reći, religija kao socijalna ili kulturna zajednica ne nestaje, ali postoje promjene u njezinom autoritetu.

»Ali da bismo razumjeli tu razliku, moramo pogledati tri različite razine ili područja u kojima se sekularizacija može pojaviti. Chaves razlaže svoju razliku između 'religije' i 'religijskog autoriteta' na temelju tri dimenzije sekularizacije Karela Dobbelaerea ${ }^{152}$ - na koje Chaves pridodaje oznake laicizam, unutarnja sekularizacija i religijsko dezangažiranje. $«^{153}$

139

Hubert Knoblauch, Sociologija religije, Demetra, Zagreb 2004., str. 153.

140

Usp. Peter E. Glasner, The Sociology of Secularisation: A Critique of a Concept, Routledge \& Kegan Paul, London 1977.; David Martin, A General Theory of Secularisation, Basil Blackwell, Oxford 1978.

141

J. K. Hadden, »Toward Desacralizing Secularization Theory«, str. 588.

142

Usp. Hans Blumenberg, Legitimnost novog veka, prev. Aleksa Buha, Izdavačka knjižarnica Zorana Stojanovića, Sremski Karlovci - Novi Sad 2004

143

Usp. Ž. Pavić, »'Sveto' u mreži dijalektike svjetovnosti«, str. 710 .

144

Usp. Rodney Stark, »Secularization, R.I.P«, Sociology of Religion 60 (1999) 3, str. 249273.

145

S. Bruce, God is Dead, str. 89.
146

Usp. P. L. Berger, Desekularizacija sveta, str. 20.

147

Usp. ibid., str. 20-21.

148

J. K. Hadden, »Toward Desacralizing Secularization Theory«, str. 588.

149

Usp. ibid.

150

Usp. Sabino S. Acquaviva, Renato Stella (ur.), Fine di un 'ideologia: la secolarizzazione, Borla, Rim 1989.

15

Ronald L. Johnstone, Religion in Society. A Sociology of Religion, Prentice Hall, New Jersey 2004., str. 369.

152

Usp. Mark Chaves, »Secularization as Declining Religious Authority«, Social Forces 72 (1994) 3, str. 749-774, ovdje str. 754-757, doi: https://doi.org/10.2307/2579779.

153

R. L. Johnstone, Religion in Society, str. 370. 


\section{Zaključak}

Razmatranje o sekularizaciji traži zajednički odnos religije i modernosti koji je prilično kompleksan. Time se otkriva očito: razmatranje o sekularizaciji nužno se pretvara u razmatranja o modernom svijetu i duhu moderniteta, zbog čega se očituje kao proces racionalizacije, a koju ne možemo izjednačiti s modernizacijom, kao što i modernizacija i sekularizacija nisu srodni fenomeni. ${ }^{154}$ Modernitet nije samo doba sekularizacije, racionalizacije i duha kapitalizma, poistovjećenoga s raščaranošću svijeta, nego i ponovni »povratak svetog «. ${ }^{155}$ Najvažnije analize procesa sekularizacije i revitalizacije religije možemo promatrati unutar nekoliko dominantnih teorija, prije svega funkcionalizma, fenomenologije i neoweberijanske tradicije.

Značenja pojma sekularizacije, unutar velikih dominantnih teorija, u velikoj mjeri proizlaze iz različitoga poimanja religije i povijesne uvjetovanosti modernosti. To pokazuje kako nastanak sekularizacije nije samo nužno način poimanja povijesne uvjetovanosti modernosti nego čak dovoljan način postojanja religije koju treba razumjeti u odmaku od klasičnih interpretacija. Zato unutar konteksta revitalizacije religije sekularizacija nas ne priječi, nego - naprotiv - obvezuje da obratimo pozornost na ono što je središte religije, a to je - Sveto. ${ }^{156}$ Stoga je važno prilagoditi stvarno religiozno iskustvo (Sveto) novim uvjetima individualnoga i kolektivnoga života. ${ }^{157}$

Nadalje, ta se dinamika, paradoksalno, očituje kroz sekularizaciju, priznajući samostalnost i smislenost svjetovnom svijetu, a to ima svoje korijene u zajedničkom iskustvu čitave jedne epohe. U tom smislu, »sekularizacija nije samo puka pojava u suvremenoj kulturnoj sceni $\ll,{ }^{158}$ koja stimulira posebne forme religije koje odražavaju duh vremena, ${ }^{159}$ »već permanentan proces u svakoj religijskoj tradiciji $\ll{ }^{160}$ Time iskustvo čitave jedne epohe pokazuje kako sekularizacija, djelujući u svojoj »domeni«, može raditi u korist Svetoga. Budući da Sveto ugrožava ili pak eliminira ono što je u religiji kao institucionaliziranoj vjeri rubno, efemerno, ${ }^{161}$ spomenuti proces društvene deregulacije religije otvara novi krug beskonačne igre institucionalne i izvaninstitucionalne religioznosti. Naime, za istaknuti je da sekularizacija u konačnici nema nikakve veze sa zbiljskim »predmetom « religioznosti, s onim što ostaje s onu stranu te dijalektike povijesne igre jer Sveto po svojoj izvornoj strukturiranosti i osebujnoj artikuliranosti jednostavno nije locirano, suviše je fluidno, satkano od najdelikatnije duhovnosti. ${ }^{162}$ Sveto, samim time, gradi most koji bi povezivao religiozni i svjetovni stav prema svijetu i egzistenciji čovjeka, a to traži i nalazi zajedničke točke, spone u jezgri koja je zajednička svakom čovjeku u duhovnosti, ${ }^{163}$ pružajući pritom otpore i najjačim prodorima sekularnih procesa. ${ }^{164}$

Za zaključiti je kako se iz sociološke perspektive religija promatra više kao sredstvo ili kulturološki oblik nego društvena institucija. ${ }^{165}$ Naime, ona traži uspostavljanje uske veze s transcendentnim, a to nas ne oslobađa od potrebe vlastitoga određenja u svijetu. Naprotiv, mišljenja smo da sekularizacija i modernitet, kao povijesni procesi, nisu filozofski nazori u kojima se čovjek shvaća kao postojanje suprotno transcendenciji. ${ }^{166} \mathrm{U}$ tom smislu, filozofski pristup religiji ima mogućnosti koje u metafizičkom smislu nisu nipošto isključivo prvenstveno društveno uvjetovane jer i one u sebi sadrže o zbilji neovisne agense-pokretačke sile koji zbilju stalno i iznova porađaju. ${ }^{167}$ Odatle i različitost postavljanja pitanja iz perspektive filozofski utemeljene sociologije i dijalektike društveno povijesnih prilika ostalih znanosti. 
Zato se razmatranje o sekularizaciji ne može zaustaviti samo na kritičkoj i povijesnoj analizi niti prihvatiti današnji pojam »religije« koji je prosvjetiteljskoga podrijetla. ${ }^{168}$ Stoga, da bi se dostiglo i razumjelo značenje fenomena sekularizacije religije, potrebna su daljnja istraživanja religije u kojima bi polazište bilo na iskustvu ontičke upućenosti prema Svetome. Ta potonja zbiljnost, prema kojoj je religija usmjerena kroz čovjekovo cjelovito unutarnje opredjeljenje bića, stoji na polovici puta između »vječnog u čovjeku« i povijesno-društvene stvarnosti. ${ }^{169}$

Revitalizacija religije »različito posreduje individualnu društvenu egzistenciju čovjeka, odgovarajući na granične situacije zahvaćanja zbilje « ${ }^{10}$ drugačije nego što to rade povijesno promjenjivi oblici ozbiljenja, kao što je to povijesni proces sekularizacije religije. Dakle, u procesu sekularizacije detektirane su manjkavosti koje traže način na koji se kontrolirati, preusmjeravati i bogatiti onim sadržajima religije koji gube na svojoj autentičnosti, omogućavajući pri tomu zloporabu integriteta, koja je ostala jedina izvjesna nada u uspjeh njihovog protivljenja revitalizaciji religije. ${ }^{171}$

Usp. P. L. Berger, »Desekularizacija sveta«, str. 13,17

155

D. Bell, » The Return of the Sacred «.

156

Usp. Esad Ćimić, Drama a/teizacije, Šahinpašić, Zagreb - Sarajevo 2006., str. 161. 157

Usp. J.-J. Wunenburger, Le sacré, str. 91; Harvey Gallagher Cox, La cité séculière: essai théologique sur la sécularisation et l'urbanisation, Casterman, Tournai 1968.; Gabriel Vahanian, La mort de Dieu: la culture de notre ère post-chrétienne, Buchet - Chastel, Pariz 1962.

158

E. Ćimić, Drama a/teizacije, str. 161. 159

Usp. Richard K. Fenn, Liturgies and Trials: The Secularization of Religious Language, Blackwell, Oxford 1981.

160

E. Ćimić, Drama a/teizacije, str. 161.

161

Usp. ibid., str. 162.

162

Usp. ibid.

163

Usp. V. Kovačević, Sekularizacija, modernitet $i$ katolički ethos, str. 276.
164

Usp. E. Ćimić, Drama a/teizacije, str. 162.

165

Usp. James A. Beckford, Religione e società industriale avanzata, prev. Silvia Aliotto, Laura Ferrarotti, Borla, Rim 1991.

166

Usp. E. Ćimić, Drama a/teizacije, str. 160.

167

Usp. V. Kovačević, Sekularizacija, modernitet $i$ katolički ethos, str. 276.

168

Usp. Franz-Xaver Kaufmann, Kako da preživi kršćanstvo?, prev. Željko Čekolj, Kršćanska sadašnjost, Zagreb 2003., str. 61 .

169

Usp. V. Kovačević, Sekularizacija, modernitet $i$ katolički ethos, str. 279.

170

Esad Ćimić, Sveto i svjetovno, Hrvatsko filozofsko društvo, Zagreb 1992., str. 183.

171

Usp. Krunoslav Malenica, Vlaho Kovačević, Goran Kardum, »Impact of Religious Self-Identification and Church Attendance on Social Distance toward Muslims«, Religions 10 (2019) 4, str. 1-18, doi: https://doi. org/10.3390/rel10040276 


\title{
Vlaho Kovačević
}

\section{From the Secularisation of Religion to the Revitalisation of Religion}

\begin{abstract}
This paper aims to pave the way for religion's potential revitalisation - outside of the ideological concept of the dialectics of contemporary society and within the historical context of the specific meaning of the secularisation of religion. Accordingly, in its understanding of religion, this paper's discussion necessarily remains beyond the dialectics of secularity, since religion is not dependent on that kind of dialectics, but on the Sacred and its comprehension. Without the Sacred, we would be in a situation of 'reoccurring of the same', as a result of which contemporary modern ideologies would negatively influence the life of the individual. The aforementioned then points to the need for multi-dimensional theoretical approaches resulting from the intricate social circumstances and various development courses of individual religions in the contemporary world. In this way the theoretical approaches to religion in contemporary society, primarily analysed based on prevalent theories of functionalism, phenomenology and the neo-Weberian tradition, exhibit diverse paradigms in their different explanations of the secularisation and revitalisation of religion.
\end{abstract}

\section{Keywords}

secularisation, religion, the Sacred, rationalisation, disenchantment, Max Weber, sociology of religion 